\title{
Governance arrangements for specialized assistance in health regions in Brazil
}

Luciana Dias de Lima 1

João Henrique Gurtler Scatena 2

Mariana Vercesi Albuquerque 3

Ricardo Antunes Dantas de Oliveira 4

Nereide Lucia Martinelli 5

Adelyne Maria Mendes Pereira 6

\footnotetext{
1,3 Departamento de Administração e Planejamento em Saúde. Escola Nacional de Saúde Pública Sérgio Arouca. Fundação Oswaldo Cruz. Rua Leopoldo Bulhões, 1480 Sala 715, $7^{\circ}$ andar. Rio de Janeiro, RJ, Brasil. CEP: 21.041-210. E-mail: luciana@ensp.fiocruz.br

2,5 Instituto de Saúde Coletiva. Universidade Federal do Mato Grosso. Cuiabá, MT, Brasil.

4 Instituto de Comunicação e Informação Científica e Tecnológica em Saúde. Fundação Oswaldo Cruz. Rio de Janeiro, RJ, Brasil.

6 Escola Politécnica de Saúde Joaquim Venâncio. Fundação Oswaldo Cruz. Rio de Janeiro, RJ, Brasil.
}

\section{Abstract}

Objectives: to analyze the regional governance arrangements of specialized assistance in the Public Health System (SUS).

Methods: Case studies were carried out which included seven health regions in the Brazilian territory, involving the secondary data systematization and 128 interviews with SUS leaders (2015 to 2016). The analysis was done in a comparative perspective, considering: public and private participation; assistance concentration; power relations and regional conflicts.

Results: the public provision service and expenditure were high in the Medium Complexity and in the private, High Complexity. The main responsibility for the public provision service was in the cities so, that the specialized assistance was strongly concentrated in the pole cities. The level of influence from the providers in health decisions was high, and the offer considered to be insufficient and inadequate in relation to services and medical professionals. Conflicts were evident in the intergovernmental and public-private relations.

Conclusions: the diversity of agents and arrangements - multilevel, hybrid and polarized - characterizes governance regionalization in SUS, which is conditioned by the scarcity and the inequality context in the distribution of services.

Key words Health policy, Health services administration, Regionalization, Health management, Public Health System 


\section{Introduction}

Since the 1980 s, several countries have experienced the reform processes related to changes in the capitalism and the role of the States with significant impacts on the health systems. Anchored in neoliberal ideas, the trends on the implemented changes were focused on the macroeconomic adjustments, reduction of public expense in social area, privatization and strengthening of markets. ${ }^{1}$

This agenda has acquired specific contours in health policy with variations in over time among countries with similar income levels and located in different regions in the world.1,2 In general, the reforms were guided for the retraction of the State in providing direct and privatization services, decentralization for sub-national governments and the introduction of market mechanisms in public system management. The characteristics and the results of the observed changes were influenced by the factors of different nature, such as, the form to insert in the health policy economy and in the social protection model and the specificity of its historical and institutional trajectory in each country.

Brazil was the only capitalist Country in Latin America, which introduced in the 1980s a universal basis health system: the Public Health System (SUS). The context of the economic crisis and the redemocratization promoted the debate and the policy action in the health area (strengthening the 'Sanitary Movement'), reflecting on the changes in the Constituição Brasileira de 1988 (Brazilian Constitution of 1988) and the health system during the 1980s. However, the guaranteed rights by the Constitution, had contributed to significant advances (such as the expansion to public services access, improvement of health indicators and alterations in the care model) the implementation of SUS expressed contradictions between conflicting agendas - the universalized health agenda and the State reform of liberal inspiration - in the coming years. ${ }^{3}$

Among other aspects, two resulted in a significant way in the State reform which were intensified in the 1990s: decentralization to sub-national entities and the stimulus for the conformation of public policy systems with a reconcentration on political resources and on federal executive fiscal, ${ }^{4}$ flexibility management and commercialization of public services associated to the 'New Public Management' proposals. 5

As the unfolding of the first reform aspect, studies demonstrate the importance of induction mechanisms and federal coordination in decentra- lizing policy-administrative in SUS, characterized by cities and the undefined role in States governments. ${ }^{6}$ Norms and federal financial incentives promote the dissemination of instituted rules in National and State levels, the configuration of federal negotiation and the diversification of intergovernmental agreements on the financial resources management and the provision of services. 7,8

However, the results on health decentralization are contradictory and highly dependent on the preconditioned locations, reflecting different financial and organizational capabilities for the provision of services and different governmental projects from Governors and Mayors. ${ }^{9}$ There are problems related to the disintegration of regional institutions, services and practices, and difficulties to form cooperative arrangements among governments that guarantees full health access. 10

The second aspect is reflected in alterations in the forms of organizing Public Administration (deployment of different modalities of the Indirect Administration, such as the State Foundations) and the introduction of different mechanisms to recruit health workforce. ${ }^{11}$ It also reflected in the expansion of the profitable and non-profitable private sector Social Organizations, philanthropic sector, private profit - in management and public provision of services. $12-14$

It should be emphasized that the boundary between the public and private health sectors is increasingly tenuous in the performance of numerous public functions by the private sector. There is still a strong correlation between public and private funding, 15 where public forms support private models (subsidy for the purchase of healthcare plans) and private resources, mainly the out-ofpocket payments paid by individuals, blending with the public funds to support the numerous health actions. 14

Based from this discussion, this article aims to analyze, in the context of health policy, the simultaneous effects of decentralizing processes, flexibility and mercantilization arrangements in regional governance by referring to specialized assistance in SUS.

This study adopts a broad conception of governance present in contemporary discussions on public management and public policy. ${ }^{16,17}$ The governance expresses dependency relations and interaction among multiple agents (State and non-State agents; public, private and corporate) under the conduct of public policies in institutional contexts. ${ }^{18}$ In this sense, the use of governance as a category of analysis enables the understanding of the regulatory intervention complexity in health, influenced by the 
acting of various interest groups and organizations in a context of reconfiguration of State power in the sector. 19,20

The justification of work is related to the importance of the expert assistance services to form networks in healthcare. ${ }^{21}$ Generally, the specialized assistance is associated to the necessity to incorporate actions that involve higher technological density and/or expertise requirement and special skills. Solla and Chioro, 22 for example, they define assistance as "a set of actions, practices, knowledge and assistance techniques typically demarcated by the incorporation of work processes that encompass the higher technological density, the so-called specialized technologies" (p.549)

Even considering the need for knowledge and specific skills in the context of primary healthcare in this study, the specialized assistance includes only the services for Medium and High Complexity (MAC) of SUS. Such services represent a significant volume of service and expenditures and it is being considered one of the greatest challenges to guarantee full health access. Especially because its provision, in addition in being guided by the offering (and not by the necessity or the epidemiological profile of the population), is concentrated and it is not adequately regulated and it is strongly influenced by private providers. 22

The regional focus, in turn, is relevant in the face of the inequalities that mark the Brazilian territory. Although, income improvements and capacity offering had occurred in 2000 to 2016, the socioeconomic differences and the composition in the health services among regions constituted for purposes to plan and manage the intergovernmental in SUS (designated as 'health areas') are quite significant. ${ }^{23}$

The article was guided by the following question: How does the governance of specialized assistance in health regions configure? It is assumed that different arrangements of governance in SUS are associated to managers' distribution of responsibilities in the provision of services and the expenditures on specialized assistance by public agents (governmental entities/spheres) and private (profitable or not) with greater or lesser regional concentration in the pole cities. The forms in how to distribute functions and the resources at this level of care express relations of power involving managers and service providers and how the health reform processes are instituted in the territory by being conditioned under specific regional dynamics.

\section{Methods}

This article is part of a National multicenter project in which the methodological steps are detailed in another publication 24 approved by the Ethics Committee of the Faculdade de Medicina da Universidade de São Paulo (CAAE: 42787815.9.1001.0065). Briefly, this research involved five case studies selected from the intentional mode in each of the Brazilian macro-regions.

This paper presented here is dedicated specifically to the analysis of the governance in specialized assistance in SUS in seven health regions encompassed in the case studies: Baixada Cuiabana (Mato Grosso-MT); North and South Barretos (São PauloSP); Carbonífera/Costa Doce (Rio Grande do SulRS); Manaus/Alto Rio Negro (Amazonas-AM); Juazeiro (Bahia-BA) and Petrolina (Pernambuco$\mathrm{PE})$. This study includes quantitative and qualitative approaches, through the systematization of secondary data from the National databanks and primary data from empirical base of the case studies.

The analysis of the cases was done in a comparative perspective, considering three dimensions: 1) public and private participation in the provision of service and the expenditures related to specialized assistance highlighting governmental entities (government levels), in case of public participation; 2 ) the concentration of specialized assistance in the city pole region; 3 ) the relation of power and conflicts regarding the specialized assistance according to regional agents.

In spite of conceptual differences and specialized assistance, in this article, they were considered as the medium and high complexity assistance (MAC). Emphasizing that this is the way it is routinely seized in information systems (outpatient and inpatient) at SUS and how the questionnaires were applied in the case studies.

The information concerning assistance for MAC, data were used from the Sistema de Informações Ambulatoriais do SUS (SIA-SUS) (Outpatient Information System at SUS) and Sistema de Informações Hospitalares do SUS (SIH-SUS) (Hospital Information System at SUS) are available online on the website DATASUS/MS, as the biennium temporal 2015-2016. This biennium was defined for analysis for three main reasons: (i) coincides with the period in which the case studies were conducted; ii) homogeneity variables selected for analysis; (iii) a reduction in the influence of any variation by the casual aggregation for two subsequent years.

The selections used on the secondary data were: 
the amount approved (procedures and Hospi-talization Authorizations-AIH), value approved, health region (Inter-managers Regional Commission-CIR), legal sphere (public administration: Federal, State, City, other; private administration: non-profit organizations; other business entities) and complexity (medium and high).

The production data and expenditures relating to such assistance were transformed into coefficients using the resident population in the regions for the referred biennium: procedures/AIH per thousand inhabitants (quantity approved x 1000/population) and per capita expenditures (value approved/population). It is also performed a simple proportion to be highlighted: public and private participation (in production and expenditures); a specific participation of the Union, States and Cities in total production and public expenditures; and the role played by the pole cities in the regions of the study.

Procedures and AIH for MAC were considered as those who are classified by SIA-SUS and SIHSUS in the "complexity" selection with a remark: in the outpatient procedures of high complexity were not included in the "medication" group (group of procedures 6), because it is common to all the investigated regions.

In addition to the data from these two systems, the information has been raised about the specialized physician work force quite related to the assistance type in the scope of this study. The Cadastro Nacional de Estabelecimentos de Saúde (CNES) (National Health Establishments Registration) was the data source, selecting: individuals (and not linked), health region (CIR) and legal sphere. The medical categories selected cover clinical specialties (16) and surgeries (17), the primary care is not considered (general practitioner, general clinician, family medicine, preventive medicine, public health physician), the resident physicians and few other specialties as legal medicine, labor and traffic.

In the same way as the production, such data were transformed into coefficients (medical specialists per 10,000 inhabitants) and percentages, showing the relation of public-private, the link with different public entities and the concentration of professionals in the pole cities.

The empirical basis of primary data originated from case studies, which the fields were conducted in seven health regions already mentioned between August 2015 (North and South Barretos) and June 2016 (Carbonífera/Costa Doce). At the time, semistructured questionnaires were applied (focusing on policy, structure, organization and intersectoriality), which differed in 10 types of instruments, depending on the category of the key agents interviewed (128): managers, providers of service and civil society representatives, City, regional and State level. For the purposes of this study, were sought, in the set of questionnaires applied, the issues that in the statement or in the choices of answer made an allusion in the specialized assistance. The issues were prioritized which expressed both power relations as conflicts between managers and providers of service in the health decisions.

Exploitation of this empirical base allowed the answers to be organized into the following categories of analysis: (a) the degree of influence in the providers of MAC at SUS (both public and private, profitable or not) in the health decisions; (b) the degree of dependence in specific services-medical consultations, diagnostic exams and hospitalizations (public and private) - for the specialized organization network in SUS; (c) sufficiency/adequacy of offering and logistical system for MAC organization in SUS; (d) Types of regional conflicts related to specialized assistance (intergovernmental and public-private).

Each study region was qualified as second predominant pattern of the interviewees' responses seized in two ways: percentage of affirmative answers exceeding $50.0 \%$, in the case of dichotomous variables (the Yes/No type); and the score above 3 (high) for the variables expressed in Likert scale (1 to 5).

It should be noted that the two regions of Barretos (North and South) as well as Petrolina (PE) and Juazeiro (BA) were analyzed altogether. These latter constitute an interstate network called PEBA, counting on management counseling made up of representatives in both regions.

At the end, from the comparison of different sources in the research data and the comparison among the cases, it was sought to characterize and define the observed governance arrangements.

\section{Results}

The public, private and the governmental entities in regional governance arrangements

Regardless of the complexity, the volume was very unequal for outpatient procedures and hospitalizations of MAC in the regions of this study, inequality was scattered per capita expenditures but not in the same proportionality (Table 1). In ambulatory assistance of medium complexity (MC), Barretos, Manaus and Baixada Cuiabana, in this order, are emphasized by both in quantity and in expenditures. 
MAC Assistance at SUS: quantity (per 1000 inhabitants), expenditures (R\$), public participation (in \%) and responsible governmental entity (in \%), when is public participation, according to health regions. Brazil, biennium 2015-2016.

\begin{tabular}{|c|c|c|c|c|c|c|c|c|c|c|c|c|}
\hline & & \multirow{3}{*}{ Health Region } & \multicolumn{2}{|c|}{ Quantity } & \multicolumn{2}{|c|}{ Expenditures } & \multicolumn{6}{|c|}{ Responsable Governmental Entity (\%) } \\
\hline & & & \multirow{2}{*}{ Proc./AIH } & \multirow{2}{*}{ \%Public } & \multirow{2}{*}{$\mathrm{R} \$$ per capita } & \multirow{2}{*}{$\%$ Public } & \multicolumn{2}{|c|}{ Federal } & \multicolumn{2}{|c|}{ State } & \multicolumn{2}{|c|}{ City } \\
\hline & & & & & & & $\mathrm{N}^{\circ}$ & $\mathrm{R} \$$ & $\mathrm{~N}^{\circ}$ & $\mathrm{R} \$$ & $\mathrm{~N}^{\circ}$ & $\mathrm{R} \$$ \\
\hline \multirow{11}{*}{ 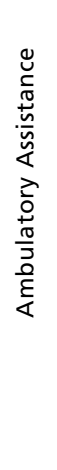 } & \multirow{6}{*}{ 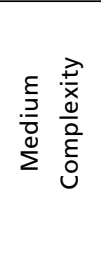 } & Baixada Cuiabana & 8714,74 & 71.98 & 64.85 & 68.62 & 7.37 & 8.63 & 12.80 & 24.75 & 79.83 & 66.62 \\
\hline & & Barretos & 12692,02 & 40.36 & 104.70 & 34.92 & - & - & 11.00 & 20.14 & 75.97 & 81.59 \\
\hline & & Carbonífera/C. Doce & 5633,15 & 33.56 & 40.36 & 34.05 & - & - & - & - & 97.80 & 97.23 \\
\hline & & Manaus/A. R. Negro & 12426,18 & 89.56 & 80.57 & 85.93 & 1.92 & 1.92 & 75.47 & 74.51 & 14.87 & 12.13 \\
\hline & & Juazeiro & 2864,72 & 63.06 & 19.56 & 58.10 & - & - & 27.49 & 26.48 & 70.17 & 71.58 \\
\hline & & Petrolina & 5049,63 & 64.48 & 29.93 & 57.59 & 11.66 & 15.04 & 65.07 & 62.12 & 20.43 & 19.53 \\
\hline & \multirow{6}{*}{ 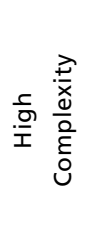 } & Baixada Cuiabana & 399.53 & 15.77 & 57.81 & 3.78 & 0.87 & 1.84 & 82.66 & 47.16 & 16.48 & 51.00 \\
\hline & & Barretos & 1389,70 & 1.58 & 218.95 & 2.07 & - & - & - & - & - & - \\
\hline & & Carbonifera/C. Doce & 62.02 & 0.47 & 10.67 & 0.64 & - & - & - & - & - & - \\
\hline & & Manaus/A. R. Negro & 135.63 & 49.50 & 23.85 & 34.42 & 4.06 & 5.53 & 95.04 & 94.24 & 0.90 & 0.23 \\
\hline & & Juazeiro & 89.10 & 8.74 & 17.15 & 12.60 & - & - & 54.47 & 96.41 & 45.53 & 3.59 \\
\hline \multirow{13}{*}{ 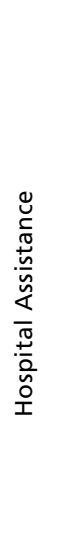 } & & Petrolina & 108.58 & 40.89 & 28.93 & 56.15 & 10.28 & 2.83 & 85.54 & 96.90 & 4.18 & 0.27 \\
\hline & \multirow{6}{*}{ 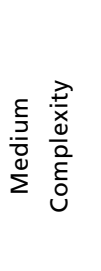 } & Baixada Cuiabana & 64.53 & 44.95 & 73.36 & 57.55 & 11.78 & 13.45 & 12.02 & 10.70 & 76.20 & 75.85 \\
\hline & & Barretos & 80.09 & 16.65 & 67.66 & 9.80 & - & - & 18.88 & 16.39 & 80.21 & 82.86 \\
\hline & & Carbonífera/C. Doce & 24.71 & 3.72 & 16.62 & 2.78 & - & - & - & - & 100.00 & 100.00 \\
\hline & & Manaus/A. R. Negro & 44.97 & 97.33 & 41.51 & 97.40 & 4.57 & 4.50 & 90.35 & 91.93 & 5.09 & 3.58 \\
\hline & & Juazeiro & 53.72 & 59.35 & 39.32 & 51.65 & - & - & 30.61 & 50.82 & 67.75 & 46.75 \\
\hline & & Petrolina & 52.89 & 97.04 & 40.94 & 97.97 & 23.83 & 29.19 & 68.79 & 66.15 & 4.92 & 2.63 \\
\hline & \multirow{6}{*}{ 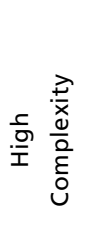 } & Baixada Cuiabana & 6.07 & 13.89 & 31.25 & 6.91 & 11.93 & 8.95 & 38.75 & 42.84 & 49.32 & 48.21 \\
\hline & & Barretos & 21.34 & 0.16 & 89.07 & 0.03 & - & - & - & - & - & - \\
\hline & & Carbonífera/C. Doce & - & - & - & - & - & - & - & - & - & - \\
\hline & & Manaus/A. R. Negro & 2.49 & 80.49 & 10.63 & 57.11 & 7.24 & 7.03 & 92.76 & 92.97 & - & - \\
\hline & & Juazeiro & 0.78 & 50.41 & 4.16 & 27.06 & - & - & 100.00 & 100.00 & - & - \\
\hline & & Petrolina & 1.68 & 81.50 & 5.50 & 50.96 & 45.32 & 48.00 & 54.68 & 52.00 & - & - \\
\hline
\end{tabular}

Source: Authors' elaboration based on data from SIA-SUS, SIH-SUS and IBGE. Note: It does not present the percentages relating to High Complexity, when the public participation on the number of visits/hospitalizations and in its expenditure was lower than $10 \%$. 
Juazeiro stood out as the neediest region, while Carbonífera and Petrolina were similar in quantitative, but differed in expenditures, assuming the implementation of simpler procedures in Petrolina. In hospital assistance for MC, Barretos and Baixada Cuiabana remained as the regions with higher volumes and expenditures, however, Carbonífera kept the indicators lower, while they were intermediaries and very near Manaus, Juazeiro and Petrolina (Table 1).

The provision of ambulatory assistance of MC and the expenditures relating to it were mostly public in four regions with emphasis in Manaus (89.6\%; 85.9\%, respectively), while in Barretos and Carbonifera, they predominated the private sector. A similar scenario occurred with hospital assistance, except for Baixada Cuiabana, where the private sector was the majority in quantitative and the public sector in expenditures. In addition, in Petrolina, the public participation in hospitalization $(97.0 \%)$ and expenditures relating to them $(97.9 \%)$ was much more than it was evident in the ambulatory assistance, similar to Manaus.

In relation to High Complexity (AC), Barretos stood out among all the regions, both in the quantity of procedures and hospitalizations, as in expenditures related to them, while Carbonífera had the lowest indicator in ambulatory assistance and had no hospitalizations of AC in the biennium in this study. Unlike the MC, the public sector participation in the provision of ambulatory assistance for $\mathrm{AC}$ was a minority in all the regions, the most evident were in: Carbonífera, Barretos, Juazeiro and Baixada Cuiabana (Table 1). In expenditures, such percentage was maintained or it reduced even more (Baixada Cuiabana and Manaus), increasing more than 50\% was only in Petrolina. Although, the private sector has also prevailed in the volume and the expenditures with hospitalizations of $\mathrm{AC}$ in Barretos and Baixada Cuiabana, the public sector in Manaus and Petrolina was the majority in volume of hospitalizations and which the expenditures has greatly been reduced.

As mentioned before, the public participation in the assistance of MC was relevant and when it happened, the framework was quite diverse, predominantly the participation of four cities (Baixada Cuiabana, Barretos, Carbonífera and Juazeiro) and the State in the other two (Manaus and Petrolina), both in the quantitative number of procedures and AIH as well as the expenditures relating to them (except in Juazeiro, where the city has concentrated hospitalizations, but it equals to the State in expenditures). At Federal level it had the lowest participa- tion and in only three regions - Petrolina, Baixada Cuiabana and Manaus -, but in the latter region it accounted for about $25 \%$ of the volume and the expenditures with MC hospitalizations (Table 1).

Now in the assistance for $\mathrm{AC}$, the provision of service was mostly private, as evidenced in the table. When the public sector accounted for an important part for this assistance, as observed in Manaus, Petrolina and Juazeiro, the State was considered as the most involved in the three regions. The Union emphasized on the important role of the provider for hospital assistance of AC in Petrolina. Even though, the public participation has been much lower in the Baixada Cuiabana, the State and the city were the main cause when this occurred (Table 1).

The assistance of MAC is quite related to medical professionals, the reason why they were investigated by some characteristics of this specialized workforce. Barretos and Baixada Cuiabana had greater availability of specialists with benefits for the first region, since it more than $85 \%$ of these professionals that worked in SUS (Table 2). In Manaus and Juazeiro, it was also high the percentage of specialists who worked in SUS, although their availability had been quite different (and much lower than in Barretos). Petrolina, Carbonífera and Baixada Cuiabana were regions with the lowest percentages of specialists linked to SUS.

A large part of the specialists who work in SUS also worked together in the private sector, ranging from $21.7 \%$ (Carbonífera) to $62.2 \%$ (Barretos), but the cities were the main (or the second) legal sphere of medical activity in the regions of Carbonifera, Juazeiro, Baixada Cuiabana and Barretos. In Petrolina and Manaus, the State with the highest concentration of specialists linked to SUS in a legal sphere (Table 2).

\section{The concentration of specialized assistance in the pole cities in the regions}

This draws attention to the importance of the pole cities in provision of regional assistance with the greatest complexity. The concentration of outpatient procedures of $\mathrm{MC}$ in the pole cities ranged from $56.2 \%$ (Barretos) to $95.8 \%$ (Manaus), next to the variation of hospitalization concentration, $56.6 \%$ (Camaquã/Guaiba, in Carbonífera) to $95.3 \%$ (Manaus), and it is even higher in expenditures concentration (Table 3).

In relation to $\mathrm{AC}$, it was exclusive (Manaus, Juazeiro and Petrolina) or almost completely (Baixada Cuiabana, Barretos and Carbonífera) provided in the pole cities in these regions, except 
Availability of medical specialists (total and SUS) per 10,000 inhabitants, working in SUS (\%), main legal spheres of activity (\%) and concentration in pole cities (\%) according to health regions. Brazil, December 2016.

\begin{tabular}{|c|c|c|c|c|c|c|c|c|}
\hline \multirow{2}{*}{ Health region } & \multicolumn{2}{|c|}{ Spec/inhab. } & \multirow{2}{*}{$\begin{array}{c}\text { \% Spec. in } \\
\text { SUS }\end{array}$} & \multicolumn{4}{|c|}{ Legal sphere (attenda at SUS) } & \multirow{2}{*}{$\begin{array}{l}\text { Conc. } \\
\text { Pole }\end{array}$} \\
\hline & Total & sus & & Fed. & St. & City & Priv & \\
\hline Baixada Cuiabana & 13.72 & 7.70 & 56.11 & 17.3 & 7.8 & 34.1 & 40.7 & 94.87 \\
\hline Barretos & 16.30 & 14.00 & 85.61 & - & 10.5 & 21.3 & 62.2 & 72.36 \\
\hline Carbonífera/C. Doce & 4.64 & 2.60 & 56.08 & - & - & 78.3 & 21.7 & 64.55 \\
\hline Manaus & 8.66 & 7.16 & 82.73 & 6.1 & 41.1 & 15.8 & 36.9 & 98.93 \\
\hline Juazeiro & 4.66 & 3.56 & 76.34 & - & 19.6 & 41.8 & 38.1 & 94.09 \\
\hline Petrolina & 8.43 & 4.29 & 50.85 & 11.9 & 44.3 & 15.7 & 28.1 & 96.12 \\
\hline
\end{tabular}

Source: Authors elaboration based on data from CNES and IBGE.

Table 3

Concentration in pole cities (in \%), the quantity and the expenditures relating to MAC assistance at SUS, according to health regions. Brazil, biennium 2015-2016.

\begin{tabular}{|c|c|c|c|c|c|}
\hline & \multirow{2}{*}{ Health region (City.) } & \multicolumn{2}{|c|}{ Medium Complexity } & \multicolumn{2}{|c|}{ High complexity } \\
\hline & & Quantity & Expenditures & Quantity & Expenditures \\
\hline \multirow{6}{*}{ 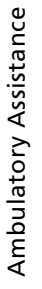 } & Baixada Cuiabana (Cuiabá) & 78.60 & 82.07 & 92.51 & 89.68 \\
\hline & Barretos (Barretos) & 56.17 & 67.14 & 96.60 & 96.00 \\
\hline & Carbonífera (Camaquã/Guaíba) & 56.75 & 61.28 & 97.57 & 97.72 \\
\hline & Manaus (Manaus) & 95.84 & 96.63 & 100 & 100 \\
\hline & Juazeiro (Juazeiro) & 79.69 & 86.21 & 100 & 100 \\
\hline & Petrolina (Petrolina) & 91.04 & 90.58 & 100 & 100 \\
\hline \multirow{6}{*}{ 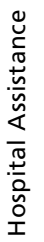 } & Baixada Cuiabana (Cuiabá) & 79.80 & 82.40 & 94.54 & 96.98 \\
\hline & Barretos (Barretos) & 59.75 & 77.19 & 99.78 & 99.96 \\
\hline & Carbonífera (Camaquã/Guaíba) & 56.61 & 62.28 & - & - \\
\hline & Manaus (Manaus) & 95.26 & 97.11 & 100 & 100 \\
\hline & Juazeiro (Juazeiro) & 66.21 & 77.90 & 100 & 100 \\
\hline & Petrolina (Petrolina) & 92.66 & 95.99 & 100 & 100 \\
\hline
\end{tabular}

Source: Authors elaboration based on data from SIA-SUS and SIH-SUS. 
Power relations and conflicts concerning the specialized assistance (MAC) second regional actors. Brazil, 2015-2016 biennium.

\begin{tabular}{|c|c|c|c|c|c|c|}
\hline & \multirow{2}{*}{ Categories of analysis } & \multicolumn{5}{|c|}{ Health Regions } \\
\hline & & $\begin{array}{l}\text { Baixada Cuiabana } \\
\text { (MT) }\end{array}$ & $\begin{array}{l}\text { Barretos - North } \\
\text { and South (SP) }\end{array}$ & $\begin{array}{l}\text { Carbonifera/Costa } \\
\text { Doce (RS) }\end{array}$ & $\begin{array}{l}\text { Manaus/Alto Rio } \\
\text { Negro (AM) }\end{array}$ & $\begin{array}{l}\text { Petrolina }(\mathrm{PE}) / \\
\text { Juazeiro }(\mathrm{BA})\end{array}$ \\
\hline 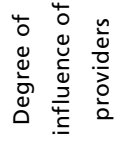 & $\begin{array}{l}\text { High degree of influence on health } \\
\text { decisions }\end{array}$ & Public and private & Public and private & Public and private & Public & Public \\
\hline \multirow{3}{*}{ 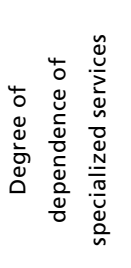 } & $\begin{array}{l}\text { High degree of dependence on } \\
\text { medical consultations }\end{array}$ & Public and private & Public & $\begin{array}{l}\text { Public and private (outside } \\
\text { the health region) }\end{array}$ & Public & Public and private \\
\hline & $\begin{array}{l}\text { High degree of dependence on } \\
\text { diagnostic tests }\end{array}$ & Public and private sectors & Private & Private & Public and private & Public and private \\
\hline & $\begin{array}{l}\text { High degree of dependence of } \\
\text { hospitalizations }\end{array}$ & Public & Private & Private & Public & Public \\
\hline \multirow{3}{*}{ 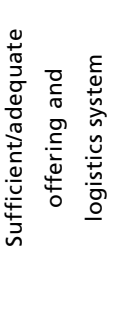 } & $\begin{array}{l}\text { Sufficiency/adequacy of offering } \\
\text { MAC* }\end{array}$ & Insufficient and inadequate & $\begin{array}{l}\text { Insufficient and inadequate } \\
\text { Exception: general hospital beds and SADT of MC. }\end{array}$ & Insufficient and inadequate & Insufficient and inadequate & Insufficient and inadequate \\
\hline & Sufficient physicians in the region & Insufficient & Insufficient & Insufficient & Insufficient & Insufficient \\
\hline & Sufficient logistical system fund ${ }^{\star *}$ & Sufficient Exception: computerized system & Sufficient Exception: computerized system & $\begin{array}{l}\text { Sufficient Exception: } \\
\text { computerized system and } \\
\text { sanitary transport }\end{array}$ & Sufficient & $\begin{array}{l}\text { Sufficient } \\
\text { Exception: computerized system }\end{array}$ \\
\hline \multirow{2}{*}{ 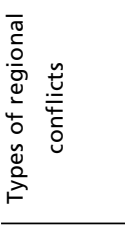 } & $\begin{array}{l}\text { Agents involved in } \\
\text { intergovernmental conflicts }\end{array}$ & $\begin{array}{l}\text { Pole City, other cities in the region, the State } \\
\text { Department of Health (SES) }\end{array}$ & $\begin{array}{l}\text { Pole City, other cities in the region, the State } \\
\text { Department of Health (SES) and Ministry of } \\
\text { Health (MS) }\end{array}$ & $\begin{array}{l}\text { Pole City, other cities in the } \\
\text { region }\end{array}$ & $\begin{array}{l}\text { Pole City, other cities in the region, } \\
\text { the State Department of Health } \\
\text { (SES) and Ministry of Health (MS) }\end{array}$ & $\begin{array}{l}\text { Pole City, other cities in the region, the State } \\
\text { Department of Health (SES), Ministry of } \\
\text { Health (MS), cities outside the region }\end{array}$ \\
\hline & $\begin{array}{l}\text { Agents involved in public-private } \\
\text { conflicts }\end{array}$ & Public managers, private provider of SUS & Public managers, private provider of SUS & $\begin{array}{l}\text { Public managers, private } \\
\text { provider of sus }\end{array}$ & $\begin{array}{l}\text { Public managers, private provider of } \\
\text { sus }\end{array}$ & $\begin{array}{l}\text { Public managers, private provider of SUS, } \\
\text { health plans }\end{array}$ \\
\hline
\end{tabular}

Source: Own elaboration based on 128 interviewees with regional key agent (Region research and Networks: paths for universal health in Brazil, 2016 )

*Sufficiency in offering: specialized consultations, general hospital beds, beds for elective procedures, neurosurgery and cardiac surgery, adult ICU, neonatal ICU, Support Service for Diagnosis and Therapy (SADT) of medium complexity, Support Service for Diagnosis and Treatment (SADT) of high complexity.

**Logistics System: medicines supply (SAF), computerized system for health services organization, central appointments for specialized consultations, central regulation for hospital beds, sanitary transport, tele-health. 
hospital assistance which was not reported in Carbonifera in the biennium of this study.

As the procedures of $\mathrm{MC}$ and $\mathrm{AC}$, the medical specialists also concentrated in cities by regions. Such concentration was a little lower in regions as of Carbonífera (64.6\%) and Barretos $(72.4 \%)$, but exceeded $94 \%$ in all the other groups (Table 3 ).

Power and conflicts relations concerning specialized assistance according to regiona agents

The influence degree of MAC providers in health decisions was high in all five regions, according to the interviewees (Table 4). In all of them, the public provider was highlighted, that are in Baixada Cuiabana, Carbonífera and Barretos, such influence was shared with the private sector.

In relation to the dependence of services for the specialized network organization, prevailed sharing public and private sectors, this is the most significant regarding medical appointments and diagnostic tests. Now, in hospitalizations, the public or private provider predominated. However, differences were observed among the regions: in Manaus, the public provider stood out in medical consultations and hospitalization, while in Carbonífera and Barretos, the private predominated in diagnostic examinations and hospitalization.

As for offering, it was considered by regional agents as insufficient and inadequate in all the regions in relation to MAC services and the medica professionals. The exceptions were the general beds and support services for diagnosis and therapy (SADT) for medium complexity in Barretos, it was perceived as sufficient for most of the interviewees. On the other hand, the logistical system was referred to as sufficient, except for the computerized system in four regions (Baixada Cuiabana, Barretos, Carbonífera and Petrolina/Juazeiro) and the sanitary transport in Carbonífera.

When considering the regional conflicts, two major types stood out, and they express in the Comissões Intergestores Regionais (CIR) (Regional Inter-managers Comission): the intergovernmental and those coming from the public-private relation. The conflict between the pole city and the others, regarding to financial resources, criteria access and network organization were common and reported in all the regions. Except for Carbonífera region, in all the others, there were also conflicts involving the State Secretaries of Health (SES). In Manaus and Barretos, the conflicts included the Ministry of Health (MS) and in Petrolina/Juazeiro, also the cities outside the region.

The resulting conflicts in the public-private relation occurred in all the regions, involving public managers and private providers of services are linked to or hired by SUS. Only in the regions of Petrolina/Juazeiro, this type of conflict also encompassed the health plan operators.

\section{Discussion}

In this study, the comparison and analysis of the empirical results (secondary and primary sources of the research), has allowed to identify similarities and differences between the cases, and establish the observed governance arrangements (Table 5).

In all the regions, there was a multilevel governance model which expresses interdependence of functions and resources among various governmental entities, 25 with a predominance of the sphere in the State and/or City officials in the provision of services and expenditures of MAC. It was identified, even, a strong articulation between the public and private specialized assistance in SUS, and an important regional concentration in the pole cities, which adds an hybrid character and polarized the governance arrangements of making it even more complex the exercise of regulatory function of regional network care.

The differences found suggest a greater public participation emphasizing on the State entity, in the regions in the North (Manaus) and Northeast (Petrolina, and in less intensity Juazeiro) in the Country. The private sphere was emphasized in the regions located in the South (Carbonifera) and Southeast (Barretos), is the predominate entity city in providing care assistance directly by the State. In Baixada Cuiabana (Midwest), the public entity city demonstrated to be particularly relevant only in the MC.

On the one hand, such pattern expresses the tendency, already observed in other studies, the expansion of the private sector linked to SUS in regions with greater economic dynamism. ${ }^{23}$ On the other hand, the evidence to the division of established responsibilities among the sub-national governments in the process of decentralizing SUS and the relevance of the States in the provision of services is more complex in regions with lower economic development. ${ }^{7}$

In the research, it draws attention to the importance of the private sector in the provision of outpatient services and very high hospital expenditures, which indicate its tendency to work in care segments are more well-paid and valued by buyers of the 
Regional governance arrangements, in assistance of MAC, according to health regions. Brazil, biennium 2015-2016.

\begin{tabular}{|c|c|c|c|c|c|}
\hline \multirow{2}{*}{ Governance Arrangements } & \multicolumn{5}{|c|}{ Health Regions } \\
\hline & $\begin{array}{l}\text { Baixada Cuiabana } \\
\text { (MT) }\end{array}$ & $\begin{array}{l}\text { Barretos - North and } \\
\text { South (SP) }\end{array}$ & $\begin{array}{l}\text { Carbonífera/Costa } \\
\text { Doce (RS) }\end{array}$ & $\begin{array}{l}\text { Manaus/Alto Rio } \\
\text { Negro (AM) }\end{array}$ & $\begin{array}{l}\text { Petrolina (PE)/ } \\
\text { Juazeiro (BA) }\end{array}$ \\
\hline $\begin{array}{l}\text { A multilevel } \\
\text { Interdependence of functions and } \\
\text { resources among various } \\
\text { governmental entities with } \\
\text { predominance sphere of the State } \\
\text { and/or city in the provision and } \\
\text { expenditures with MAC } \\
\text { Hybrid }\end{array}$ & $\begin{array}{l}\text { Governmental interdependence with predominance of the } \\
\text { city sphere }\end{array}$ & $\begin{array}{l}\text { Governmental interdependence with } \\
\text { predominance of the city sphere }\end{array}$ & $\begin{array}{l}\text { Governmental interdependence } \\
\text { with predominance of the city } \\
\text { sphere }\end{array}$ & $\begin{array}{l}\text { Governmental interdependence } \\
\text { with predominance of the state } \\
\text { sphere }\end{array}$ & $\begin{array}{l}\text { Governmental interdependence } \\
\text { with predominance of the state and } \\
\text { city sphere }\end{array}$ \\
\hline $\begin{array}{l}\text { Elevated dependence and/or in } \\
\text { public and/or private provision and } \\
\text { expenditures with } \mathrm{MC} \text { and } \mathrm{AC} \text { at SUS } \\
\text { and high degree of influence of } \\
\text { public and/or private providers in the } \\
\text { decisions in the health region }\end{array}$ & $\begin{array}{l}\text { Elevated public dependence in } \mathrm{MC} \text { and private } \mathrm{AC} \text {, with a } \\
\text { high degree of public and private influence }\end{array}$ & $\begin{array}{l}\text { Elevated private dependence in MAC, with a high } \\
\text { degree of public and private influence }\end{array}$ & $\begin{array}{l}\text { Elevated private dependency in } \\
\text { MAC, with a high degree of } \\
\text { public and private influence }\end{array}$ & $\begin{array}{l}\text { Elevated public dependence in } \\
\text { MAC, with a high degree of public } \\
\text { influence }\end{array}$ & $\begin{array}{l}\text { Elevated public dependence in MAC, } \\
\text { with a high degree of public } \\
\text { influence }\end{array}$ \\
\hline $\begin{array}{l}\text { Typology of regional governance } \\
\text { arrangements in health }\end{array}$ & $\begin{array}{l}\text { Type 1: governmental interdependence with strong } \\
\text { participation of the city sphere of the regional pole and } \\
\text { public and private providers in health decisions in the } \\
\text { region. }\end{array}$ & $\begin{array}{l}\text { Type 1: governmental interdependence with } \\
\text { strong participation of the city sphere of the } \\
\text { regional pole and public and private providers in } \\
\text { health decisions in the region }\end{array}$ & $\begin{array}{l}\text { Type 1: governmental } \\
\text { interdependence with strong } \\
\text { participation of the city sphere, } \\
\text { of the regional pole and public } \\
\text { and private providers in health } \\
\text { decisions in the region }\end{array}$ & $\begin{array}{l}\text { Type 2: governmental } \\
\text { interdependence with strong } \\
\text { participation of the state sphere of } \\
\text { the regional pole and public } \\
\text { providers in health decisions in the } \\
\text { region }\end{array}$ & $\begin{array}{l}\text { Type 3: governmental } \\
\text { interdependence with strong } \\
\text { participation of the city and state } \\
\text { sphere of the regional pole and } \\
\text { public providers in health decisions } \\
\text { in the region }\end{array}$ \\
\hline
\end{tabular}


private health planst. ${ }^{26}$ As indicated by the interviewees, the degree of influence of private providers of MAC in the health decisions was high and shared with the public sector in some regions. Such aspect reinforces the findings of other studies that deepen in the aspects of contract and regulating access, highlight the power of influence in the private sector in regional governance. $27-29$

The high dependence of specialized services, the insufficiency and inadequacy of offering care (including specialized consultations, diagnostic exams and hospitalizations), and the concentration of provision and expenditures in the pole cities by making it possible to understand the role to differ service from public and private providers in the regions. It should be pointed out that the lack of medical specialists has been a problem identified in various health systems in the world, and that, in the case of the Brazilians, this issue is exacerbated by inequalities in the regional distribution of these professionals. 30

Particularly, in case of Manaus and Petrolina/ Juazeiro, the influence of public providers can be explained by the importance of the State entity in the provision and expenditure of MAC. In the region of Carbonifera is distinguished from the others because it is extremely dependent and subject to the influence of providers located in other health regions.

According to the interviewees', the logistic systems were insufficient. These systems contribute in all levels of health management and should facilitate both the operation of networks linked to health, as well as the production of strategic and relevant information to negotiate and make decision in health policy. 21 The lack of computerized system in all regions is a great concern, because it can lead to power asymmetry to an extreme that the institutions produce and retain the information does not necessarily make it accessible and disseminate in the region. Such asymmetry involves different spheres of government, pole cities and other towns and public and private providers, and can affect the degree of influence of each participant in their decisions about health regions.

The concentration of care, financial and informational resources in the pole cities and in certain governmental entities and providers (public or private), is associated with the conflicts which mark the governance in the studied regions. Most of them, the State Secretaries of Health (SES) stood out in regional conflicts giving its relevance in the regional coordination process and the resources and services that administrate these regions.

Some special features distinguish the regions to study and promote different governance arrangements, in terms of specialized care. Baixada Cuiabana and Manaus are regions that are home State Capitals, concentrating MAC services and demanded by them, both in the region and as the State. Such situation, in which generates the involvement of various institutional agents in the regional governance by expanding the range of conflict, which in case of Manaus, also includes the Ministry of Health.

The pole city in the region of Barretos has a MAC service (philanthropic, linked to SUS) that generates an increased demand in the State, and even National levels. This will influence the governance of that region with the participation of three State entities and, especially the private sector where the most specialists work. Not by chance, the range of agents involved in conflicts is wide-intergovernmental organizations or public-private- in this region.

Juazeiro and Petrolina, comply an interstate region (PEBA) and have in their MS an important agent for regional governance, even if its role is in the provision of services of MAC in which concentrates more in Petrolina. Both regions are distant from other urban centers that focus resources from MAC, counting on the participation of relevant SES, but also private providers linked to SUS, especially in the ambulatory care. The broad spectrum of conflicts reported in the region is the reflection in the amount of agents involved in the provision of services and the complexity of managing them in an interstate region.

In Carbonífera region it does not include the State Capital, it does not have MAC services or State/Country reference and it is also not isolated. It distinguishes from the others, among other characteristics for being contiguous to the health region Capital/Vale Gravataí, which includes Porto Alegre, the Capital and the main State reference center for specialized assistance. Such situation helps to understand the low number of visits to specialized assistance (quite dependent on the private sector) and of medical specialists. The limited assistance from MAC, under the responsibility of the cities and the private sector linked to SUS, and concentrated in two cities in this region, suggests a regional governance involving a smaller number of agents and explains the conflicts reported.

As pointed out by the results of this study, when the focus is on MAC assistance, there are several regional governance arrangements involved with various agents, depending on the region. Although, the connections between the agents and the variety 
of relations are the predominant characteristic, empirical base exploited allows to relate to the main agents of the regional governance of MAC. In this order: 1) pole regional City; 2) private providers linked to SUS; 3) the City government or the State; 4) the Federal government.

The shortage and the absence of a uniformed distribution of services reflect the territorial inequalities, which marks the context of governance assistance of MAC in health regions in Brazil. In addition, to the high degree of dependence in relation to the pole Cities and the private providers that directly impact on the architecture of power and, in arrangements of observed regional governance. This context results in political disputes for scarce resources, both from the intergovernmental relations' point of view, as the public-private relations, and, also, in the competition of private-public to influence the decisions of health in the regions.

As a summary of the findings, the research also allowed to identify three types of regional governance arrangements in health (Table 5). The first comprises the largest number of regions-Baixada Cuiabana (MT), Barretos - North and South (SP) and Carbonífera/Costa Doce (RS), the second one refers to the region in Manaus/Alto Rio Negro (AM) and the third the regions of Petrolina/Juazeiro (BA). In the three types, there is always governmental interdependence and that the variations occur in relation to the importance of the participation of the sphere State and private providers in the decisions of health in the region.

The definition of these three types of arrangements suggest some tendencies of the reform process in the State in health with influence on regional governance of SUS: the weight of decentralizing Cities; the growing influence of the private sector in the provision of service and expenditures, but also the decisions of health; the inequalities in relation to power involving poles and non-poles Cities, as a result of the urbanization pattern and the extreme regional concentration in the provision of specialized services in few Cities in the Country; and the importance to participate of the State sphere in the provision of services and expenditures with MAC, giving greater influence in the public sector in decisions about health in some regions.

Finally, some limitations of this article and its potential effects should be mentioned: (a) the population base to calculate indicators that quantify the production of MAC and its expenditures was in the region, which may be less than that, in fact, uses such services, overestimating such indicators; b) the option to investigate individuals and not job links, in case of medical specialists, although it is more appropriate to quantify these professionals, subdimensional of such workforce, given various job links and the circulation of specialists between distinct legal spheres; c) the interviewees' in the case studies were mostly public institutional agents which may have overestimated the role of the State.

However, these limitations do not compromise the inferences here made on the governance of MAC. The identification of the agents and the characteristics of the various arrangements - multilevel, hybrids and polarized -, with variations among regions, is the main contribution of this study to understand the tendency of the regional governance of specialized assistance and challenges related to the regionalization in SUS.

\section{References}

1. Almeida C. Reforma do Estado e reforma de sistemas de saúde: experiências internacionais e tendências de mudança. Ciênc Saúde Coletiva. 1999; 4 (2): 263-86.

2. Almeida C. Reforma de sistemas de servicios de salud y equidad en América Latina y el Caribe: algunas lecciones de los años 80 y 90. Cad Saúde Pública. 2002; 18 (4): $905-$ 25.

3. Paim JS, Travassos C, Almeida C, Bahia L, Macinko J. The Brazilian Health System: history, advances, and challenges. Lancet. 2011; 377: 1778-97.

4. Hochman G, Faria CAP, organizadores. Federalismo e políticas públicas no Brasil. 1 ed. Rio de Janeiro: Editora Fiocruz; 2013

5. Costa FL. Reforma do Estado e contexto brasileiro: crítica do paradigma gerencialista. 1 ed. Rio de Janeiro: Editora
FGV; 2010.

6. Viana ALd'Á, Machado CV. Descentralização e coordenação federativa: a experiência brasileira na saúde. Cien Saude Colet. 2009; 14(3): 807-817.

7. Viana ALd'Á, Lima LD, Oliveira RG. Descentralização e federalismo: a política de saúde em novo contexto - lições do caso brasileiro. Ciênc Saúde Coletiva. 2002; 7 (3): 493507.

8. Dourado DA, Elias PEM. Regionalização e dinâmica política do federalismo sanitário brasileiro. Rev Saúde Pública. 2011; 45 (1): 204-11.

9. Souza C. Governos e sociedades locais em contextos de desigualdades e de descentralização. Ciênc Saúde Coletiva. 2002; 7 (3): 431-42. 
10. Campos GWS. Efeitos paradoxais da descentralização do Sistema Único de Saúde do Brasil. In: Fleury S, organizadora. Democracia, descentralização e desenvolvimento: Brasil e Espanha. Rio de Janeiro: FGV; 2006. p. 417-42.

11. Martins MIC, Molinaro A. Reestruturação produtiva e seu impacto nas relações de trabalho nos serviços públicos de saúde no Brasil. Ciênc Saúde Coletiva. 2013; 18 (6): $1667-$ 76.

12. Bahia L. A démarche do privado e público no sistema de atenção à saúde no Brasil em tempos de democracia e ajuste fiscal, 1988-2008. In: Lima JCF, Matta GC, organizadores. Estado, sociedade e formação profissional em saúde: Contradições e desafios em 20 anos de SUS. Rio de Janeiro: Editora Fiocruz; 2008. p. 123-85.

13. Barbosa NB, Elias PEM. As organizações sociais de saúde como forma de gestão público/privado. Ciênc Saúde Coletiva. 2010. 15 (5): 2483-2495.

14. Ocké-Reis CO. SUS: o desafio de ser único. 1a Ed. Rio de Janeiro: Editora Fiocruz; 2012.

15. Santos IS, Ugá MAD, Porto SM. O mix público-privado no sistema de saúde brasileiro: financiamento, oferta utilização de serviços de saúde. Ciênc Saúde Coletiva. 2008; 13 (5): 1431-40

16. Rhodes RAW. The new governance: governing without government. Political Studies. 1996; XLIV: 652-67.

17. Stoker G. Governance as theory: five propositions. Int Soc Sci J. 1998; 50 (155): 17-28.

18. Marques EC. Government, political, actors and governance in urban policies in Brazil and São Paulo: concepts for future research agenda. Braz Political Sci Rev. 2013; 7 (3): 8-35.

19. Jakubowski E, Saltman RB, editor. The changing nationa role in health system governance. A case-based study of 11 European countries and Australia. Brussels: The European Observatory on Health Systems and Policies/WHO; 2013.

20. Greer SL, Jarman H, Azorsky A. A reorganisation you can see from space: the architecture of power in the new NHS London: Centre for Health and Public Organization; 2014.
21. Mendes EV. As redes de atenção à saúde. $2^{\mathrm{a}}$. Ed. Brasília: Organização Pan-Americana da Saúde; 2011.

22. Solla J, Chioro A. Atenção ambulatorial especializada. In: Giovanella L, Escorel S, Lobato LVC, Noronha JC, Carvalho I, organizadores. Políticas e sistema de saúde no Brasil. Rio de Janeiro: Editora Fiocruz; 2012. p. 547-76.

23. Albuquerque MV, Viana ALd'Á, Lima LD, Ferreira MP, Fusaro ER, Iozzi FL. Desigualdades regionais na saúde: mudanças observadas no Brasil de 2000 a 2016. Ciênc Saúde Coletiva. 2017; 22 (4): 1055-64.

24. Viana ALd'Á, Ferreira MP, Cutrim MAB, Fusaro ER, Souza MR, Mourão L, Chancharulo AP, Mota PHS. Política de regionalização do SUS em debate: avanços e impasses da implementação das regiões e redes no Brasil. Novos Caminhos [nota técnica on line] 2017. [acesso em 29 mai 2017] 15:8p. Disponível em: www.regiaoeredes.com.br

25. Peters GB, Pierre J. Developments in intergovernmental relations: towards multi-level governance. Policy Polit. 2001; 29 (2): 131-5

26. Santos MAB, Gerschman S. As segmentações da oferta de serviços de saúde no Brasil: arranjos institucionais, credores, pagadores e provedores. Ciênc Saúde Coletiva. 2004; 9 (3): 795-806

27. Santos AM, Giovanella L. Governança regional: estratégias e disputas para gestão em saúde. Rev Saúde Pública. 2014; 48 (4): 622-31.

28. Almeida APS, Lima LD. O público e o privado no processo de regionalização da saúde no Espírito Santo. Saúde Debate. 2015; 39 (Spe): 51-63.

29. Romano CMC, Scatena JHG, Kehrig RT. Articulação público-privada na atenção ambulatorial de média e alta complexidade do SUS: atuação da Secretaria de Estado de Saúde de Mato Grosso. Physis. 2015; 25 (4): 1095-1115.

30. Scheffer M, Guilloux AGA, Matijasevich A, Massenburg BB, Saluja S, MD, MPP, Alonso N. The state of the surgical workforce in Brazil. Surgery. 2017; 161 (2): 556-61.

Received on June 1st, 2017

Final version presented on July $10^{\text {th }}, 2017$

Approved on September 20th, 2017 